\title{
Social Security: Personal Investment Accounts (PIAS)
}

Elizabeth C. Ekmekjian, (E-mail: EkmekjianE@wpunj.edu), William Paterson University Berch Haroian, William Paterson University Tricia Snyder, William Paterson University

\begin{abstract}
Today, the Social Security payroll tax is the largest tax that the average American family pays. Social Security is also the largest government program in the United States, with almost half of all government receipts going to pay for Social Security. Concerns about the long-term solvency of Social Security have produced numerous options for Social security reform. Among the more interesting proposals was that made by President Bush that would allow individuals to manager their own private investment accounts (PIAs). In this paper, we examine the potential effects of PIAs be ones age and gender. We also examine the tax consequences of the proposed PIAs and other potential concerns of PIAs.
\end{abstract}

\section{INTRODUCTION}

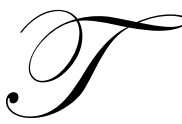
Security currently pays benefits of almost $\$ 408$ billion to more than 45 million people, including retired workers, disabled workers, the spouses and children of disabled workers, and the survivors of deceased workers.

Social Security has always been largely a pay as you go system. This means that current worker' taxes pay current retirees' benefits. As a result, the relative numbers of workers and beneficiaries has a major impact on the program's finances, also making the level of benefits for each generation not related to their contributions. The ratio of workers to benefit recipients is changing for the worse and is represented in Table 1.

Table 1

\begin{tabular}{|c|c|}
\hline \multicolumn{2}{|c|}{ Ratio of Workers Benefits } \\
\hline 1950 & $16.5: 1$ \\
\hline 1960 & $4.2: 1$ \\
\hline 2003 & $3.4: 1$ \\
\hline 2030 & $2.1: 1$ \\
\hline
\end{tabular}

Thus, in 1950 before major additions of beneficiaries were made, the ratio was 16.5:1. However, by 2030, GAO estimates that the number of recipients relative to the number of workers is expected to drop to 2 to 1 . By the year 2011, when the baby- boom generation starts turning 65 , the number of Social Security recipients is expected to grow faster than the U.S. labor force, leading to fewer workers to pay taxes for each retiree, reducing Social Security's rate of return (USA Today, February 24, 2004). Further, there are several structural problems facing the system. Among these are: a) individuals are retiring early and living longer; $b$ ) the fertility rate per female has been declining from around 3 children per female in the 1960's to an estimated 1.95 in 2030, which is below the replacement rate.

Concerns about the long-term solvency of Social Security have produced numerous options for Social security reform. Alternatives run the gamut from increasing the retirement age threshold to reducing the dollar value of benefits. 
Among the more interesting proposals was that made by President Bush that would allow individuals to manager their own retirement savings. In his State of the Union Address he suggested that we should allow individuals to manage their own retirement funds through Social Security Investment Accounts by saying that we should "give younger workers an opportunity to set aside a portion of their Social Security taxes in personal retirement accounts."

These Investment accounts are also known as Personal Investment Accounts (PIAs). Although Social Security provides for a wide range of benefits from disability to survivors benefits, this paper is concerned with only that portion of the program that provides for worker retirement benefits. Thus, we attempt to answer the question as to whether an individual is better off continuing in the current program or opting for investment in a PIA. In addition, we have included a brief analysis of some of the tax consequences of opting for a PIA.

\section{MODEL}

In this paper, we hope to determine the best way to maximize an individual's financial after tax return for a Social Security system. To do this, we must consider the expected benefit and costs under the current and proposed PIA Social Security Accounts. Since a standard rate of return cannot be applied to a "pay as you go" Social Security program, economist use an implicit rate of return based on a person's expected cost (contributions in the form of taxes) and expected benefit (receipt of social security payments).

In Social Security Choice, Tanner states that a common measure of Social Securities expected return is the benefit-to-tax ratio. The benefit-to-tax ratio provides a ratio of the present value of expected benefits divided by the present value of expected payroll taxes. Since the expected Social Security benefits depend on life expectance, the model must incorporate the expected time frame of life expectance, which differs greatly depending on gender. Statistically women have a greater expectance than men and therefore draw benefits for a much longer time frame. This ratio can be written as:

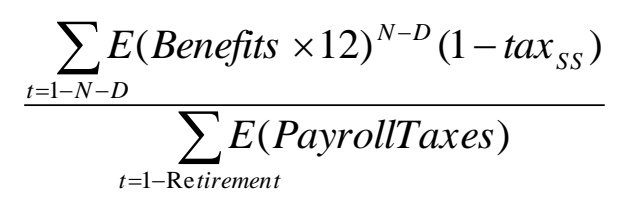

where Benefits are the monthly Social Security Benefit, $N$ is an estimation of life expectancy, $D$ is the age that one is eligible to draw Social Security, time period before the recipient draws Social Security, thus $N-D$ is number of years one might expect to draw Social Security or the time period one receives Social Security benefits, $\operatorname{tax}_{S S}$ is the Social Security tax rate one faces while drawing social security, $t$ is the time period, Payroll Taxes are assumed to be the current social security payroll taxes at the maximum for the employee's yearly contributions into social security for the years of expected work, and 1-Retirement represents the working years and the time period one pays into Social Security. ${ }^{\mathrm{i}}$ Benefits are assumed to be the maximum monthly benefits for each demographic group.

\section{METHODOLOGY}

The basic question that we address in this paper is that given the current Social Security system and the proposed PIA's, where is an individual's financial interest maximized? Further, since females earn less than males and live significantly longer, in which program is their financial interest maximized? Finally, we explore certain tax consequences of the proposed PIA's versus current tax consequences of receiving Social Security benefits.

In order to establish a basis of comparison, we first review the dollar contribution of a retirement age male in year 2004, with his expected dollar benefits. We have seen that this individual can expect to receive almost 1.5 times his contribution as a benefit.

Next, we take a male, age 40, at average national wage and compute a) his SS contribution and retirement benefits-exclusive of COLA adjustments; b) invest in a conservative PIA where money is invested 50\% in Blue Chip stocks 
and 50\% in United States Government Bonds (US Bonds). Two choices are provided to take all the money as an annuity benefit or moderate the drawdown to provide a balance at death that could be a bequest to one's heirs. Further, this information is reformulated in an aggressive fund 30\% Blue Chips, 20\% Growth stocks, and 50\% US Bonds. The same two choices of either maximum payout or provide a balance for a bequest. The same methodology is applied to a 40 year old female with the same investment choices. These results are then summarized in the several Tables to be found throughout this paper.

Finally, a mutual fund investment of $\$ 10,000$ in 1991 is examined as to its value since $100 \%$ investment may not be feasible. The results are both surprising and informative.

\section{BACKGROUND}

As a basis for comparison we set forth below the expected Social Security Benefits (SSB) for a male retiring under the current program and eligible for maximum benefits in the year 2004. The worker would need to meet the age test of 65 years 4 months, and would have an expected longevity of 79.84 years. The SSB entitlement would be $\$ 1,825$ per month. The benefit period would be for 14 years 6 months or 174 months. The total benefit, exclusive of any cost of living adjustments (CPI) would be $\$ 317,550$. The financial contribution of this individual would have been $\$ 88,266$ and an additional $\$ 110,383$ from the employer's side. Thus at retirement age there would be a dollar sum equivalent to $\$ 198,649$ providing a monthly benefit of $\$ 1825$.

As a basis for comparison, in the current year an individual who had contributed the maximum to SS for the prior years and opted to retire at the age of 65 years 4 months would be entitled to $\$ 1825$ per month for his expected life span of 79.8 years. The value of this benefit, exclusive of COLA would be $\$ 317,550$. The total contributions on the part of individual and employer would total $\$ 198,649$. In the event of death at or prior to age 79.8 there are no benefits for heirs. The above represents a return of $156 \%$.

\section{MALE AT RETIREMENT 2004-PIA}

We have seen the dollars that this person would receive from SS, let us now compare a stock market based investment instead of mandatory SS contributions. Alternatively, if the retirement funds had been invested conservatively; $50 \%$ in "Blue Chip stocks" ( historically a 7.0\% return) and 50\% in US Bonds (historically a $3.0 \%$ return). The value at retirement would be $\$ 732,435$ and provide for a monthly benefit of $\$ 5,629$ until age 79.8 . In addition if the monthly benefit withdrawn, is reduced to $\$ 2,815$, some $\$ 715,000$ would be available at death to be passed onto one's heirs as a bequest. These results are summarized in Table 2.

Table 2

\begin{tabular}{|c|c|c|c|c|}
\hline \multicolumn{5}{|c|}{ Summary of Benefits } \\
\hline & Total Accumulation & Monthly Benefits & Total \$ Received & Bequest \$ \\
\hline SSB & $\$ 198,649$ & $\$ 1825$ & $\$ 317,550$ & None \\
\hline PIA & $\$ 732,435$ & $\$ 5629$ & $\$ 979,446$ & None \\
\hline PIA & $\$ 732,435$ & $\$ 2815$ & $\$ 489,810$ & Yes \\
\hline
\end{tabular}

In summary, the traditional view that early investment no matter how modest will provide long term benefits continues to hold. It should be noted that the above figures are exclusive of Cost of Living increases or administrative/management fees.

\section{THE AVERAGE WORKER}

In section 1 we were able to see that PIA investment even for a person at the high end of the income scale provided significant advantages over the traditional and narrowly defined SSB payment. Our next examination is that of the relevant payments and accruals for an average worker at age 40 in 2004. An average wage of $\$ 56,354$ was assumed with 
the current structure of SS. The total contributions to the fund would thus total $\$ 274,877$, and a benefit at retirement (age 67 ) of $\$ 2,161$. Longevity is estimated to be 77.8 years. Thus the total paid benefit thru SS would be $\$ 276,608$ for a return of just about $100 \%$ on the original contribution. Alternatively had these funds been invested in the same 50-50 conservative way as in section 1 the PIA would have been $\$ 893,343$ which would provide a solo benefit of $\$ 7,277$ per month with no heir bequest possible. At a reduced rate $\$ 3638$ some $\$ 720,338$ could be available for your heirs.

Should a more aggressive (riskier) investment strategy be followed such as Blue Chips 50\%; Start-up stocks 20\%; US Bonds $30 \%$, the total accumulation increases to $\$ 1,186,873$. This would provide for a draw down of $\$ 9,668$ or $\$ 4,834$ to provide a bequest of some $\$ 1,058.146$ for your heirs. These results are summarized in Table 3 below.

Table 3

\begin{tabular}{|c|c|c|c|c|}
\hline \multicolumn{5}{|c|}{ Summary of Benefits } \\
\hline & Total Accumulation & Monthly Benefits & Total \$ Received & Bequest $\$$ \\
\hline SSB & $\$ 274,877$ & $\$ 2,161$ & $\$ 276,608$ & None \\
\hline \multicolumn{5}{|c|}{ Conservative Investment } \\
\hline PIA & $\$ 893,343$ & $\$ 7,277$ & $\$ 931,456$ & None \\
\hline PIA & $\$ 893,343$ & $\$ 3,638$ & $\$ 465,408$ & Yes \\
\hline PIA & $\$ 1,186,873$ & Riskier-Investment & None \\
\hline PIA & $\$ 1,186,873$ & $\$ 9,668$ & $\$ 1,237,504$ & Yes \\
\hline
\end{tabular}

As the above data demonstrate PIAs consistently deliver more dollars for an individual at every level of investment from the conservative to that of modest risk. ${ }^{1}$ received?

Another topic that needs to be addressed is the gender issue. Can the longer longevity of women affect the benefits

\section{THE GENDER ISSUE}

How would the duality of lower female wages and longer longevity affect the payment of SSB or PIAs? We carried out an equivalent analysis on a female at age 40 , with an average wage of $\$ 30,467$ with longevity of 84 years. Retirement age is 67 years. Given the above, this individual would accrue only $\$ 141,964$ and the monthly benefit from SSB would be $\$ 1,399$. The lifetime benefit would be $\$ 285,396$ or over a $200 \%$ return on the $\$ 141,964$ fund amount. However, invested conservatively (50-50) the total fund amount would increase to $\$ 522,980$ and provide a full monthly benefit of 4,260 (almost triple the SSB amount) or at a reduced rate of $\$ 2,130$ the bequest amount could be $\$ 561,736$.

A more aggressive investment strategy (50-20-30) would provide $\$ 710,326$ and a monthly benefit of $\$ 5,786$ or at reduced benefit rate $\$ 2,893$ a benefit bequest of $\$ 895,987$ could be possible. Table 4 illustrates these results.

1 It should be kept in mind that the above data are exclusive of administrative fees or management costs and do not include COLA'S. 
Table 4

\begin{tabular}{|l|c|c|c|c|}
\hline \multicolumn{5}{|c|}{ Summary of Benefits for Female Age 40 } \\
\hline & Total Accumulation & Monthly Benefits & Total \$ Received & Bequest \$ \\
\hline SSB & $\$ 141,964$ & $\$ 1,399$ & $\$ 285,396$ & None \\
\hline \multicolumn{5}{|c|}{ Conservative Investment } \\
\hline PIA & $\$ 522,980$ & $\$ 4,260$ & $\$ 869,040$ & None \\
\hline PIA & $\$ 522,980$ & $\$ 2,130$ & $\$ 434,520$ & Yes \\
\hline Riskier-Investment & $\$ 710,326$ & $\$ 5,786$ & $\$ 1,180,344$ & None \\
\hline PIA & $\$ 710,326$ & $\$ 590,172$ & Yes \\
\hline PIA
\end{tabular}

The above data confirm that financial interests would be best served whether either by conservative or riskier investments. Given the lower earnings of women and their longevity the benefit appears to be consistently in favor of PIAs. The earlier the investment the higher the earnings and the potential drawdown over time.

\section{TAX CONSEQUENCES}

Prior to 1984, social security retirement benefits escaped taxation. However, in 1983, an amendment to section 86 of the Internal Revenue Code (IRC) provided for the taxation of up to $50 \%$ of benefits if a taxpayer's income exceeded a specified base amount. This shift in policy was based on the wherewithal to pay concept: a taxpayer has the means with which to pay the tax. Legislation in 1993 provided an expansion of the application of this concept. As a result, up to 85\% of a taxpayer's social security benefits may be included in taxable income.

Two formulas are used for determining taxable benefits. The formulas and certain related definitions are provided in the footnotes. ${ }^{\text {ii }}$ These complex rules are simplified as follows:

1. If modified adjusted gross income (MAGI - income items such as salary, interest (taxable and non-taxable) and dividends, without regard to social security income) plus $1 / 2$ of social security benefits is between $\$ 0$ and $\$ 25,000$ $(\$ 32,000$ in the case of a joint return (MFJ)) - none of the taxpayer' social security benefits are taxed.

2. If MAGI plus $1 / 2$ of social security benefits is between $\$ 25,000$ and $\$ 34,000$ (between $\$ 32,000$ and $\$ 44,000$ if MFJ) - up to $50 \%$ of benefits may be taxed.

3. If MAGI plus $1 / 2$ of social security benefits is greater than $\$ 34,000$ ( $\$ 44,000$ if MFJ) - up to $85 \%$ of benefits may be taxed.

For example: Claire and Jody are married and file a joint tax return. Their income in 2004 consists of: salary $\$ 25,000$; dividends $\$ 2,000$; tax exempt municipal bond interest $\$ 3,000$; and social security benefits $\$ 18,000$. MAGI is calculated as follows: $\$ 25,000+\$ 2,000+\$ 3,000=\$ 30,000$. Since MAGI plus $1 / 2$ of social security benefits totals $\$ 39,000$ $[\$ 30,000+(\$ 18,000 \times .50)]$, rule (2) above applies and up to $50 \%$ of benefits or $\$ 9,000$ may be taxed.

It should be noted that this income is taxed as ordinary income. Simply stated, taxable social security benefits do not receive preferential tax treatment similar to qualified dividends and long-term capital gains. These two income items are taxed at either $5 \%$ (if a taxpayer's marginal rate - highest rate that is applied in computing the tax liability - is $10 \%$ or $15 \%$ ) or $15 \%$ (marginal rate is $25 \%$ or higher). These special tax rates provide added incentives for taxpayers to invest in stocks, bonds and other capital assets.

Will the government change current tax policy as it concerns social security benefits? If a taxpayer establishes a PIA that invests in stocks and bonds, how will a gain from the sale/ exchange of stock, as well as dividend income be taxed: as ordinary or capital? How will capital losses be treated? 


\section{POTENTIAL CONCERNS WITH PIA's}

While there are several potential benefits to private investment accounts, there are also several potential problems with all of the proposed plans. The first and the largest potential problem with private investment accounts are that they all have investment risk. While the stock market has experienced close to a ten- percent return over the past forty years, this return is by no means guaranteed. Over the long run, stock prices rise in relation to corporate profits and profits grow in proportion to growth in the economy. So a slow-growing economy means that stock prices will rise slower than in the past. In fact, stock returns fluctuate considerably from year to year. According to Cordes and Steuerle, over the past 70 years stock returns were actually negative in nearly one out of every four years, making the benefit amount a recipient receives time dependent and vary greatly between one year and the next.

A second potential problem is the administrative costs associated with private investment accounts. Dean Baker, an economist at the Economic Policy Institute in Washington D.C., suggests that the administrative costs, including sales commissions and annual management fees will run close to $1 \%$ of all returns. Britain's privatized pensions cost closer to $2 \%$ a year. This may eliminate much of the potential benefit of private investment accounts. Furthermore, Francis suggests that employers would have to bear the heavier administrative costs of deducting small amounts of money from each employee and sending it to whichever firm each employee specifies.

Many have proposed that to avoid these high administrative costs, the government should establish a Federal private investment account division to run all investments. While this may reduce the administrative costs it also generates a greater potential problem with the government intervening in private capital markets. As Cordes and Steuerle point out, does it make sense for the U.S. government as a whole to engage in arbitrage, and if they do does it create bizarre incentives or at the very least a conflict of interest. Some believe that a large equity stake in the trust fund would increase the potential for the U.S. government to intervene in private capital markets. For example, there is significant evidence both in foreign countries and in state capitals that pressures continually arise to control investment, such as increases in public works projects or reductions in purchases of tobacco and alcohol stocks (see Cordes and Steuerle).

Cordes and Steuerle also point out that there are both welfare and the individual equity gains from Social Security, suggesting that another problem with private investment accounts is that income redistribution would not be possible under a privatized system. Currently, the Social Security formula is fixed to give a better deal to the poor than to the rich. For instance, someone who earns $\$ 30,000$ every year for his entire career pays half as much Social Security tax as someone who earns $\$ 60,000$ a year for his entire career, but gets just 29 percent less in benefits upon retirement. These sorts of transfers can happen only because everyone's Social Security taxes go into one big pot. If everybody saves for himself, you can't give the poor a better deal (see, Chait). In other words, social security taxes subsidize lower-earning workers. However, under private investment accounts, there would be no redistribution of income between highly paid and lower paid workers. Retirement benefits received by each participant would be directly proportional to their accumulated contributions and the return paid on those contributions (see Cordes and Steuerle).

A similar redistribution issue is how gains from privatization would be shared among future generations. Suppose that benefits and taxes are both cut back proportionately in a pay-as-you-go system (whether by 10 percent or 100 percent each) in order to finance some privatization. Because Social Security has a progressive benefit formula and a roughly proportionate tax formula, the hit would be proportionately larger for those with lower incomes. That is, the proceeds of Social Security contributions that are now shared in a way those benefits lower-income workers would instead be distributed proportionately to income. As a consequence, whatever the gains to future participants, future high-income workers would gain disproportionately.

Another concern of private investment accounts is that it encourages risky investment behavior. Privatization proposals that would allow individuals to "keep" gains from private accounts in good times but require the government to maintain a floor in bad times would encourage individuals to take excessive risk. The consequences to the government would be similar to those when the savings and loan financial sector essentially went bankrupt and would be financed by current workers, making the current worker bear the risk, while the retiree bears none. An often overlooked issue is that under a system in which all or part of future retirement income is financed from private accounts the government is left 
with a large liability to cover the needs of those who failed to attain an adequate income due to falling markets or poor unlucky investment.

Private investment accounts ignore the fact that 80 percent of payroll deductions will be needed for decades to come to pay the pensions of current retirees and those near retirement, according to Francis. In the short-run private investment accounts would worsen the financial condition of Social Security, since some of the taxes now needed to cover the traditional benefits to current retirees would be lost to tap into the set up of private investment accounts (USA Today, February 24, 2004.) The Social Security Administration estimates that this cost will be close to 1.5 trillion over the next decade. In essence, while private investment accounts may be a better deal for younger workers, it is not for retirees or those nearing retirement.

\section{CONCLUSION}

We have examined the issue of the current SS program versus PIAs and conclude that on a straight financial basis, the dollar value of PIAs exceeds the narrowly defined SS benefit by a wide margin. The current SS program continues to benefit workers both male and female that are at or near the retirement age. For all others, a total or partial investment in PIAs provides a greater total dollar portfolio and, depending upon one's investment strategy. even provides for death bequest to one's heirs. Our examination has not taken into account COLA's, administrative fees or management fees for PIAs. In addition, the transitional or management costs and the impact on the current SS program have not been examined.

The viability of private investment accounts is of interest not only to the government sector, but also to the private investment sector, labor unions, and senior citizen associations, such as AARP. Assuming that the goal of the government is to maximize overall welfare, it is important for policymakers to understand the full impacts of private investment accounts. In this paper, we evaluate the major differences between the current Social Security system and private investment accounts. To do this, we will compare the history, financial structure, and the potential gains and losses of both programs.

\section{REFERENCES}

1. Cordes, Joseph J. and C. Eugene Steuerle, A Primer on Privatization Funding Through Private Individual Accounts Versus the Social Security Trust Fund, Urban Institute, www.nationalissues.com.

2. Francis, David, Beware Privatization, The Christian Science Monitor.

3. Ip, Greg Greenspan Favors Entitlement Cuts The Wall Street Journal, February $26^{\text {th }}, 2004$.

4. John, David C. Social Security Reform: And Now for the Hard Part The Heritage Foundation, www.heritage.org.

5. Tanner, Michael The Better Deal: Estimating Rates of Return Under a System of Individual Accounts Social Security Choice, www.socialsecurity.org.

6. Walker, David M. Social Security: Analysis of Issues and Selected Reform Proposals United States General Accounting Office, Testimony Before the Special Committee on Aging, U.S. Senate. GAO-03-376T, January $15,2003$.

\footnotetext{
${ }^{\mathrm{i}}$ It is assumed that beneficiaries pay the maximum marginal income tax rate, which is applicable to .85 percent of the benefits.

${ }^{\text {ii }}$ Formulas for determining taxable social security benefits are contained in section 86 of the Internal Revenue Code and are presented below along with a definition of the term "modified adjusted gross income." If modified adjusted gross income (MAGI) + 50\% of SS retirement benefits exceeds the Base 1 amount (2004 Base 1 amounts $=\$ 25,000, \$ 0$ for married taxpayers who do not live apart for the entire year but file separate returns, or $\$ 32,000$ if married filing a joint tax return), taxable benefits are the lesser of: (a) .50 (SS retirement benefits) or (b) $.50[\mathrm{MAGI}+.50(\mathrm{SS}$ retirement benefits) - Base 1 amount]. If modified adjusted gross income (MAGI) $+50 \%$ of SS retirement benefits exceeds the Base 2 amount (2004 Base 2 amounts $=\$ 34,000, \$ 0$ for married taxpayers who do not live apart for the entire year but file separate returns, or $\$ 44,000$ if married filing a joint tax return), taxable benefits are the lesser of: (a) .85(SS retirement benefits) or (b) the sum of (i) .85 [MAGI +.50 (SS retirement benefits) - Base 2 amount] and (ii) the lessor of: - the amount included through application of Formula 1 . above or $\$ 4,500$ ( $\$ 6,000$ if married filing jointly). $*$ The term Modified Adjusted Gross Income is defined as: adjusted gross income less social security benefits (less income items found in sections 135, 137, 221, 222, 011, 931 and 933 of the IRC) plus tax exempt interest income. Section 86(b)(2) of the IRC.
} 
NOTES 
${ }^{\mathrm{i}}$ It is assumed that beneficiaries pay the maximum marginal income tax rate, which is applicable to .85 percent of the benefits.

${ }^{\text {ii }}$ Formulas for determining taxable social security benefits are contained in section 86 of the Internal Revenue Code and are presented below along with a definition of the term "modified adjusted gross income." If modified adjusted gross income (MAGI) + 50\% of SS retirement benefits exceeds the Base 1 amount (2004 Base 1 amounts $=\$ 25,000, \$ 0$ for married taxpayers who do not live apart for the entire year but file separate returns, or $\$ 32,000$ if married filing a joint tax return), taxable benefits are the lesser of: (a) .50(SS retirement benefits) or (b) .50[MAGI +.50 (SS retirement benefits) - Base 1 amount]. If modified adjusted gross income (MAGI) $+50 \%$ of SS retirement benefits exceeds the Base 2 amount (2004 Base 2 amounts $=\$ 34,000, \$ 0$ for married taxpayers who do not live apart for the entire year but file separate returns, or $\$ 44,000$ if married filing a joint tax return), taxable benefits are the lesser of: (a) .85 (SS retirement benefits) or (b) the sum of (i) .85 [MAGI +.50 (SS retirement benefits) - Base 2 amount] and (ii) the lessor of: - the amount included through application of Formula 1. above or $\$ 4,500$ ( $\$ 6,000$ if married filing jointly). * The term Modified Adjusted Gross Income is defined as: adjusted gross income less social security benefits (less income items found in sections 135, 137, 221, 222, 011, 931 and 933 of the IRC) plus tax exempt interest income. Section 86(b)(2) of the IRC. 